\title{
The Politics of Trade: Fast Track's Failure Derails the New Economy
}

\author{
Ken Kerot
}

Ken kero will complete the master of public administration prostam at The George Washington University in May 1998 with a concentration in public policy and the lesislative process. Ken is the legislative assistant to Rep. Ellen

0. Tauscher (D-CA) where he is the Representative's principal advisor on trade. the environment (including Superfund. water. natural resources, and regulatory matters). child care issues. judiciary. boreign abfairs. education. say and lesbian issues. and agricullure. He received a bachelor of arts from GWU in Intemational Abtairs (1992).

The views expressed in this article are those of the aluthor.

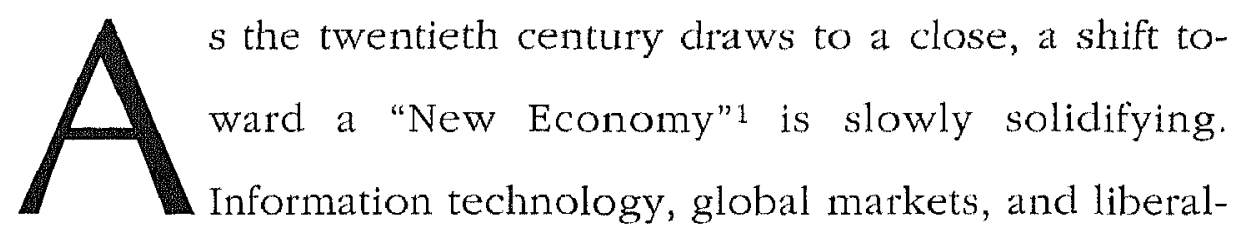
ized trade policies have increased wealth around the world, yet there remains an underlying nervousness in the American psyche about trade policy and, in particular, a pervasive fear that open borders lead to job loss. This fear is at the heart of the recent, failed attempt by Congress to re-authorize the president to use his long-standing authority to negotiate trade agreements through the procedure known as Fast Track.

The debate over Fast Track was deeply mired in the politics of big business, labor, the environment, executive-legislative relations, constitutional conflict, and partisan warfare. After a long and arduous struggle in which advocates and opponents found themselves in strange alliances, Fast Track was defeated.

The various complexities of trade policy necessitate cohesive U.S. leadership to protect national economic interests in the 
Without the full

participation of

the world's

largest trading

partner, the New

Economy cannot

reach its full

potential. international global market. The defeat of Fast Track was thus a step backward for the emerging New Economy and a lesson in political mobilization, partisan cooperation, and the importance of a well-framed and publicly supported issue. Without the full participation of the world's largest trading partner; the New Economy cannot reach its full potential. In this new climate, understanding how and why Fast Track failed is crucial to ensuring successful trade policy formulation in the future.

The failure of Fast Track demonstrates how domestic political concerns and the constitutionally established system of checks and balances between the executive and legislative branches can impede policy goals. A simple procedural device established nearly 25 years ago, Fast Track would allow the president to negotiate trade deals with foreign governments and then submit the resulting agreement to Congress; additionally, Fast Track rules require debate to occur in Congress within a specified time before allowing a straight up-or-down vote on the completed trade agreement. There is no opportunity for amendments, which contributes to the speed of the process. President Clinton's economic policy is based squarely on the "New Democrat"2 strategy of eliminating foreign barriers to U.S. exports, and Fast Track authority to enter into such negotiations was one of his most important legislative priorities for the first session of the 105th Congress.

The failure to pass Fast Track in 1997 reveals that without public sup- port, future trade accords will be exposed to demagoguery by free trade opponents. The executive and legislative branches must work closely with other free trade advocates to explain the connection between international trade, job growth, and the New Economy. Concerns over environmental interests, job losses, and human rights issues must also be addressed. State and community leaders, foundation heads, academics, and citizens must join in this national debate. The American people need to gain familiarity with the benefits that can be derived from lowering and even eliminating trade barriers, including better jobs, less expensive goods, and an improved economy. Short-sighted protectionism and legislative micro-management ignore the long-term benefits of the $\mathrm{New}$ Economy. If we fail to learn these lessons, future attempts to secure passage of Fast Track or free trade agreements will be met with equally fierce and successful opposition.

\section{Shared Authority - and Tension - in Foreign Affairs}

To better understand the complexity of the Fast Track debate, one must initially examine the fundamental problems that arise when two branches of government share responsibility for an issue. As is the case with trade, ${ }^{3}$ neither the president nor Congress can operate effectively or successfully without the support of the other. The Constitution grants the president supremacy in foreign affairs ${ }^{4}$ but provides Congress the abili- 
ty to raise and levy tariffs and control commerce. ${ }^{5}$ Accordingly, negotiating trade deals with foreign governments that may affect tariffs or other domestic laws requires a cooperative relationship between the executive and legislative branches. The shared authority - and tension - exist by constitutional design. The key lies in channeling that tension into comprehensive policies that serve the U.S. in the global economy.

For many years, Congress directly authorized "the Executive to bargain over trade reciprocity with no necessity of subsequent legislative action." "6 According to Congress, any presidential authority to enter into trade negotiations when tariffs or domestic laws may be changed occurs only at the expressed direction of that body. The president is able to negotiate trade deals without congressional consent but, without Congress' authority, there is no guarantee the House and Senate will pass the agreements unchanged. This constitutional gridlock between the two branches has yielded varying degrees of temporary supremacy for both the executive and Congress, resulting in the Fast Track mechanism. ${ }^{7}$

\section{The Trade Act of 1974}

In the early 1970s, members of Congress, seeking increased input in trade policy matters, enacted the Trade Act of $1974,{ }^{8}$ which established the Fast Track mechanism as a tool for meeting the constitutional requirements for trade policy development. Fast Track, which was the first formalized method for trade policy formulation, was consistently reaulthorized from 1974 until 1994 under both Democratic and Republican administrations.

Since its inception during the 93rd Congress, "this expedited legislativeapproval mechanism has exhibited enormous versatility as a procedural device to secure congressional-executive cooperation in the management of United States international trade policy." This act provided the president the credibility necessary to negotiate agreements while ensuring ongoing executive accountability to congressional concerns.

The 1974 act provided that trade agreements "could enter into effect with respect to the United States, and that required changes would be made in domestic law, only if both Houses of Congress, by a majority vote of those present and voting, approved implementing legislation. In order to assure that a vote would be taken on such trade agreements, however... proceclural rules involving time limits, discharge petitions, limitation on debates, and a prohibition on amendments" 10 were also added to ensure congressional participation as well as presidential credibility in trade negotiations.

Fast Track "allowed Congress to overcome both the political inertia and the procedural obstacles that frequently prevent a controversial measure from coming to a vote at all." 11 Additionally, further executive "checks" were established by requiring the president to notify the House Ways and
The American

people need to

gain familiarity

with the benefits

that can be

derived from

lowering and

even eliminating

trade barriers,

including better

jobs, less

expensive goods,

and an improved

economy. 
Means Committee and the Senate Finance Committee at least 90 days before beginning negotiations with trading partners. ${ }^{12}$ One- and two-house disapproval procedures (or legislative vetoes) ${ }^{13}$ were included for specific

Fast Track

"allowed

Congress to

overcome both

the political

inertia and the

procedural

obstacles that

frequently

prevent a

controversial

measure from

coming to a vote

at all." provisions within the negotiating process. ${ }^{14}$ Since that time, and until its recent defeat, the Fast Track procedure was the basic framework for authorizing U.S. trade agreements.

\section{Increased Congressional Oversight}

When Congress reauthorized Fast Track in 1984, several changes were incorporated into the legislation as a result of the decision in Immigration and Naturalization Service $v$. Chadba, a 1983 Supreme Court case. In this important case, the Court invalidated the legislative veto, which was one of the congressional oversight tools included in the Trade Act of $1974 .{ }^{15}$ As a result, and to ensure ongoing congressional consultation, Congress strengthened the role of the "gatekeeper" committees, i.e., the House Ways and Means Committee and the Senate Finance Committee, ${ }^{16}$ in the following year in the Trade and Tariff Act of 1984. ${ }^{17}$ Under this measure, a "majority vote of either committee could 'derail' a presidential proposal from the Fast Track... thereby giving the Executive strong incentives to consult with the committee's members at each step in the process." 18 In the wake of Chadba and the loss of the legislative veto, Congress took steps to restore the balance of power with the executive branch and strengthen the consulta- tive process between the two branches in trade negotiations. ${ }^{19}$

As Fast Track was set to expire in 1991, President George Bush requested an extension to continue negotiating the North American Free Trade Agreement (NAFTA) but met stiff opposition from members of Congress who were concerned about labor and environmental issues. Although direct conflict was averted and trade negotiations were allowed to resume, ${ }^{20}$ this brief clash was an ominous sign of what lay ahead. The historic debate regarding the conflict of congressional or executive primacy was overshadowed by questions about the New Economy as well as domestic and international environmental and labor interests.

The battle over NAFTA during the 103rd Congress in 1993 highlighted the changing lens through which trade relations and the New Economy were being viewed. The growth and strength of various labor and business interest groups led to a highly contentious debate. ${ }^{21}$ In order to secure passage, President Clinton and free trade supporters were compelled to make promises and cut deals with members of Congress to gain their votes. ${ }^{22}$ After debating trade, foreign policy, labor, and the environment for nearly a year; Congress passed NAFTA by a vote of 234-200 in the House and $61-38$ in the Senate. ${ }^{23}$ Following the difficult vote on NAFTA, Congress was averse to providing additional trade negotiating authority to the executive and Fast Track expired at the end of 1994. 


\section{Focus on Fast Track}

After his election to a second term in 1996 and the re-election of a Republican-controlled Congress, President Clinton decided to focus once again on trade and the need for Fast Track. As a New Democrat who embraced the New Economy, the president acknowledged early on that labor and environmental matters could make this a difficult fight. With few exceptions on either side, big business and high-tech firms strongly supported free trade while organized labor and environmentalists strongly opposed it. From the beginning, free trade advocates acknowledged that the Republican majority in the House lacked sufficient backing to pass Fast Track and that support from Democrats would be needed. ${ }^{24}$

In the ensuing debate, many members of the House and Senate worked to ensure the passage of Fast Track. On the Senate sicle, both Majority Leader Trent Lott (R-MS) and Minority Leader Tom Daschle (D-SD) secured the votes of sixty-nine of that chamber's one hundred members to support a procedural motion to begin debate on re-authorizing Fast Track. ${ }^{25}$ With that level of support assured in the Senate, the focus shifted to the House of Representatives. There, House Speaker Newt Gingrich (R$\mathrm{GA}$ ), despite past differences with the president, led the effort to secure the Republican votes necessary for passage.

Meanwhile, the majority of Democrats in the House worked with equal enthusiasm to prevent Fast Track's renewal. Presidential politics may have spurred the ambition of Democratic Leader Dick Gephardt of Missouri (who will reportedly challenge Vice President Al Gore in the Democratic presidential nominating process in 2000) when he staked a position independent of the White House on an issue he hopes will motivate and mobilize party activists in the next presidential election. With Vice President Gore firmly ensconced as a Fast Track supporter, Gephardt "established himself more than ever as the favorite presidential aspirant of organized labor, which is once again the party's most conspicuous power center."26 Gephardt's leadership against Fast Track was an important addition to the dynamics of the matter.

Congressional opponents took issue with the non-amendability of trade agreements negotiated under Fast Track. Supporters and the president countered that without this provision trading partners of the United. States would simply not go through the exercise of negotiating a trade deal if Congress were allowed to make changes following its conclusion. According to one editorial supporting Fast Track, the

"reality is that if Congress is allowed to change the contents of agreements, negotiations would never end. It is simply impractical for 535 people in Congress to thrash out the details of trade agreements, To be timely and effective, that authority must be delegated, just as union members delegate to their leaders the authority to work out labor contracts with business leaders." 27
The battle over

NAFTA during

the 103rd

Congress in 1993

highlighted the

changing lens

through which

trade relations

and the New

Economy were

being viewed. 


\section{Big business and}

\section{high-tech firms}

strongly

supported free

trade while

organized labor

and

environmentalists

strongly opposed

it.

\section{Opponents and Advocates}

\section{Strong Opposition: Labor and Environmental Groups}

The traditional Democratic labor and environmental constituencies began working privately to oppose Fast Track in early 1997, meeting with members to express, in the strongest terms, their intention to oppose the traditional trade negotiating authority and to hold members accountable for their votes. In the words of one labor lobbyist, the vote on Fast Track would be the "top priority... the one [by] which the unions will judge members" 28 in the elections of November 1998. This was a powerful argument to many Demo-crats who had not forgotten the loss of 40 years of congressional control to the GOP when labor stayed home on Election Day in 1994 following the NAFTA vote in the 103rd Congress.

Representatives of organized labor and environmental issues opposed Fast Track because the trade agreements negotiated under this device would inevitably bring job loss as corporations and lower-skilled manufacturing jobs moved to lowerwage nations. Labor supporters claimed that well-paying American jobs were moving overseas as corporations took advantage of weak or nonexistent labor, environmental, and consumer safeguards in foreign countries. This loss, critics argued, destroyed good U.S. jobs by depressing domestic wages and undermining laws designed to protect the health and safety of America's working families,
Other arguments made by Fast. Track opponents were less substantive. While they pointed out that workers' rights and environmental protections were minimal abroad, critics simultaneously downplayed the fact that increased American investment plays an important role in improving foreign economies and thus the well-being of foreign workers. Labor unions consistently linked Fast Track to NAFTA by arguing that the North American Agreement on Labor Cooperation (NAALC), which was concluded as a side agreement to NAFTA in $1993,2^{29}$ had done little to improve the standard of living for workers and was inadequate primarily because the agreement lacked sufficient provisions for enforceability. 30 Here again, critics ignored the reality that Fast Track simply authorizes the president to enter into trade negotiations without determining the eventual outcome.

Environmental issues, both in the United States and abroad, profoundly influence congressional votes and act as an impetus for mobilizing organizations. Environmental groups were nearly unified in their opposition to at Fast Track extension in 1997. Like the labor-related agreements in NAFTA, the supplemental agreements on environmental protection in that pact were viewed as falling short of expectations. 31 The administration countered that "institutions created under the environmental agreements (in NAFTA) provide opportunities for both governments and citizens of the three NAFTA parties to interact at all levels, ensuring that the public's con- 
cerns regarding environmental matters will be heard and facilitating joint efforts to address common environnental prohlems." 32

\section{strong Support: Economic and \\ Foreign Policy Concerns}

Supporters of Fast Track provided compelling evidence that the nation's current economic recovery is directly dependent on increased foreign trade. ${ }^{33}$ Today's "combination of low unemployment, steady growth, and low inflation in the United States would be inconceivable without openness to the global economy." 31 For example, in California nine percent of the Gross State Product (GSP) is based on trade and in the past ten years California's exports have increased 200 percent. Last year alone, Californians embraced the New Economy and exported $\$ 99$ billion worth of high-tech, pharmaceutical, and other manufactured goods worldwide. With 96 percent of the world's population living outside U.S. borders, the importance of access to those consumers is clear.

Proponents further argued that higher-wage, higher-skilled jobs in America resulted from increased trade and that such benefits could only be realized if more trade barriers were eliminated. Supporters substantiated this argument with an example from the 1950s when many low-wage industries moved from the Northeast to southern states, which certainly

"cost some New Englanders their jobs. A generation later, New England is not simply richer. It is richer in relation to the national average than it was 40 years ago, when the flight of the mills was beginning. Meanwhile southern prosperity has grown even faster. The disparities between the country's richest states and its poorest are significantly narrower than they were in the 1950.." 35

The United States may lose certain low-wage, low-skilled jobs when industries move their production facilities to developing countries as trade barriers are eliminated. While this loss may bring some temporary isolated hardship, the overwhelming global interest is positively affected in the long-term. Just like New England and the South, both America and the developing world will benefit from free trade. As a nation's workers begin to shift their demands from simply having a job to worker rights and the quality of their environment, the citizens of developing countries inevitably benefit. ${ }^{36}$

Supporters raised the foreign policy and national security implications of the failure of Fast Track. Free trade supporters claimed that the U.S., ats the sole remaining superpower, had a fundamental interest in enhancing peace and prosperity by linking economies and increasing trade. According to Secretary of State Madeleine K. Albright, without Fast Track

"our ability to influence nations in other areas of critical interest to the United States would be diminished. If we disengage and turn inward, further trade agreements will be concluded without our imprint...

\section{With Vice}

President Gore

firmly ensconced

as a Fast Track

supporter,

Gephardt

"established

himself more

than ever as the

favorite

presidential

aspirant of

organized labor,

which is once

again the party's

most

conspicuous

power center." 
With 96 percent

of the world's

population living

outside U.S.

borders, the

importance of

access to those

consumers is

clear.
[I]f we do not lead on trade, it will be very difficult to exercise leadership on other vital foreign policy matters." ${ }^{37}$

Although a rallying cry for supporters, this argument, like others, had little resonance with Fast Track opponents. Since the end of the Cold War, members of Congress no longer hold such arguments in high regard.

\section{Conditional Support: Business Sits}

\section{on the Sidelines}

Business and industry groups who support the reduction of trade barriers did not begin their lobbying efforts until the final Fast Track authorizing legislation was passed by the House Ways and Means Committee in October 1997. Concerns persisted in the business community that the president might buckle to his traditional Democratic constituencies and include, from the business point of view, undesirable labor and environmental standards; thus, the business community offered only very limited assistance to the early attempts to gather support from members of Congress and the public.

Advocates on Capitol Hill from both parties repeatedly urged businesses to lobby members more aggressively on the issue, even with the condition that the definitive support of the business community would hinge on the contents of the final bill. Despite these urgings, many members complained that "business leaders failed to drum up support for trade agreements," 38 and therefore "no one in Congress felt any particu- lar pressure or demand to support"39 the measure.

Business leaders further failed to explain the importance of free trade and Fast Track to their employees, leading legislators to criticize CEOS who had neglected to educate their employees on the importance of free trade. By withholding support for Fast Track until October 1997, the business community provided labor groups and other opponents an additional six months to get commitments from members to oppose the measure. Many Democrats who otherwise might have opted to support Fast Track were locked in early as opponents. As a result of the "timid" and "incompetent" ${ }^{40}$ business leadership, many of the 45 members of the moderate, pro-trade "New Democrat Coalition" announced themselves as opponents even before the White House had presented its Fast Track re-authorization bill to Congress.

\section{Intergovernmental Relations}

Armed with the knowledge that the debate on Fast Track would be highly contentious and acknowledging the reality of Republican control of Congress, President Clinton and his administration set out to clesign a proposal that could be supported by a majority of Republicans and some Democrats. Following months of consultation with the House Ways and Means Committee and the Senate Finance Committee, as well as free trade supporters from both parties, President Clinton, after much delay, unveiled his proposal for Fast Track on September 16, 1997. While the 
proposal was similar to past Fatst Track measures, ${ }^{41}$ the president attempted to mollify opponents by expanding the ability to promote environmentally sustainable development and worker rights abroad. ${ }^{+2}$ As is common in such a controversial atmosphere where compromise is sought, the proposal was derided by both the left and right on those two issues.

Chairman Bill Archer (R-TX) of the House Ways and Means Committee continued working with the aldministration. Republicans, and outside groups to pass Fast Track legislation through his committee and on to the floor of the House. ${ }^{43}$ After working over the first weekend of October and through the night of October 6, 1997 , the Ways and Means Committee and the administration developed compromise language on the controversial labor and environmental provisions and introduced H.R. 2621, the Reciprocal Trade Agreement Authorities Act of 1997. 'Two days later, the Committee considered the bill and sent it to the full House by a vote of 24-14.45 The fact that only four of the Committee's 20 Democrats supported H.R. 2621 was perhaps the most telling sign that trouble lay ahead for the administration. Representative Charles Rangel (D-NY), the ranking member of the Committee, refused to support the bill, stating that although the measure "may give the president the tools he needs to provide economic leadership around the world, it unfortunately does not give the president the tools he needs to provide economic leadership at home." 46 Domestic politics had transcended the economic rationale for liberalized trade and the need for Fast Track.

\section{Lobbying Among Democrats}

The fact that the ranking Democrat on the Committee responsible for trade opposed the bill presiged the difficulty the president would have in garnering the support of members of his own party. A group of Democratic opponents of Fast Track established an effective operation to kecp Democratic support for the initiative to fewer than fifty votes. The group "met regularly in a huddle to strategize against the president." 7 According to Rep. Gephardt, this debate was about "whether we connect our values of environmental quality, worker and human rights to our economic policy." 48

Still, a core group of approximately 15 Democratic supporters met several times a week throughout September, October, and November to strategize and work with the administration to pass Fast Track. While some members had less than substantive reasons for their indecision, most uncommitted members had genuine conflicts and concerns about the bill and felt that the administration, business groups, and other supporters had failed to adequately show why Fast Track deserved their vote. A great effort was made to accommodate individual members' concerns.

\section{Lobbying Among Republicans}

Historically, a majority of Republican members of Congress supported measures to reduce trade barriers. Yet despite traditionally promoting lusi-

\section{According to}

Secretary of State

Madeleine K.

Albright, without

Fast Track

"our ability to

influence nations

in other areas of

critical interest to

the United States

would be

diminished." 


\section{By withholding}

support for Fast

Track until

October 1997,

the business

community

provided labor

groups and other

opponents an

additional six

months to get

commitments

from members to

oppose the

measure. ness interests, sufficient support from the party was not assured. A strong protectionist wing of the Republican party exists, as well as a smaller prolabor group, providing Fast Track opponents the potential margin necessary to assure defeat. Furthermore, the administration found itself "running head-on into Republicans who don't trust the president," 49 Speaker Gingrich, a committed supporter, asked Republican Whip DeLay (TX) to handle the operations on that side of the aisle and many described "the lobbying by their leadership as the most intense they had seen." 50 The GOP leadership worked within the party, with outside interest groups, and with the White House to ensure the requisite number of votes to secure passage. ${ }^{51}$ America Leads On Trade, a coalition of pro-trade business interests, as well as the U.S. Chamber of Commerce and other groups worked in tandem with both Democratic and Republican supporters to find the votes for passage. Unfortunately, these often effective lobbying operations began too late in the process and many organizations that were expected to back Fast Track did not publicly support the measure until days before the vote was scheduled to occur - too late to produce the groundswell of support necessary to ensure passage and provide political cover for uncommitted members.

\section{Cautious and Limited Presidential}

\section{Leadership}

The timing of the initiative to reauthorize Fast Track also created a difficult situation for the White
House. Many pro-trade Democrats had already angered labor by supporting the Most Favored Nation ${ }^{52}$ status for China in June and felt they could not again vote against the interests of this important constituency. Furthermore, as the final appropriations bills to fund the government were being resolved, some Republicans threatened to oppose Fast Track unless the White House acquiesced to some of their priorities, such as international family planning, census sampling, and national education testing. These Republicans were "in no hurry... to knock themselves out to give Clinton yet another legislative victory, even if they generally support the objective." 53

The presidency carries a substantial amount of leverage to promote the executive's agenda and the president can potentially provide a considerable amount of leadership. ${ }^{54}$ However, many have argued that Clinton was ineffective in using his leadership on the re-authorization of Fast Track. Although the president presented his legislation to Congress on September 16, 1997, the presentation came nearly a week after the Fast Track "roll-out" ceremony at the White House. The president was unable to secure the support of the necessary advocates before sending the bill to Congress, causing concern that the administration's proposal would be "dead on arrival." Members of Congress complained consistently throughout the fall of 1997 that the White House "had not been effective in answering the objections of House Democrats and convincing them of 
the benefits of free trade." 55 The American people and Congress remained unconvinced that this trade negotiating authority was necessary or warranted.

The art of politics allows changes to be made in legislation to allay the concerns of individual members and resolve their problems, and such "horse-trades" are made frequently, 56 The daily "wheeling, dealing, wheedling and arm-twisting" between the executive and legislative branches of government is critical when controversial measures are priority items for the nation's leaders and can often provide the votes necessary for passage. ${ }^{57}$ Such wheeling and dealing was very much in evidence during the Fast Track debate. Although the executive branch is legally forbidden from directly lobbying members of Congress, ${ }^{58}$ the president "made numerous deals to win votes." 59 The president and the vice president both pledged to back Democratic members who anticipated a loss of needed financial support from labor as a result of their support for Fast Track.

\section{Fast Track Fails}

During the final week before the vote, lobbyists from outside organizations streamed to the Hill to meet with members and their staffs. Representatives on both sides of the issue frantically tried to convince those who remained undecided to vote with them. Well-attended press conferences announcing new support or opposition were held.
President Clinton invited undecided members to the White House for lengthy discussions about their concerns in order to gain the necessary support. During whip meetings, members spoke openly about what it would take to bring members to support the president, and results were often produced. But the opposition to Fast Track was stronger than its support. Confronted "with the failure of a frenetic, down-to-the-wire lobbying campaign, President Clinton... called House Speaker Newt Gingrich at 1:15 a.m. [on Monday, November 10, 1997] and asked him to remove the bill from a vote that had been scheduled for later that morning." 60

Despite all the deals the administration could make, the pressure put on Republican members by their leadership, and the admittedly late lobbying efforts by the business community, a vote on Fast Track by the full House did not occur. In the end, President Clinton decided to pull the bill rather than suffer a humiliating defeat that could have hindered future attempts to pass tracle-related legislation. In a statement on the South Lawn of the White House the following morning, the president expressed disappointment because "we worked very hard and we're very close to having the requisite number of votes. But early this morning it became clear to me that if the matter were taken to a vote there was a substantial chance that we would not get the votes necessary to pass the bill." $" 61$ With that statement, Fast Track was dead for 1997.

\section{Domestic politics}

had transcended

the economic

rationale for

liberalized trade

and the need for

Fast Track. 
$\ln 1997$, free

trade opponents

exploited

Americans'

economic and

international

insecurities to the

detriment of U.S.

national interest.
The nation and Congress remained uncomfortable with the New Economy and unsure that additional trade deals are necessary. Although the president stated in his 1998 State of the Union Address that he intends to renew his "request for the Fast Track negotiating authority," the fate of those words remains to be seen.

\section{Analysis}

At the clawn of the twenty-first century, Fast Track's failure has imperiled America's leadership of, and participation in, the New Economy. In 1997, free trade opponents exploited Americans' economic and international insecurities to the detriment of U.S. national interest. These opponents were assisted in their mission by a mischaracterization of trade as a vehicle of loss - loss of jobs, loss of national sovereignty, and loss of pride in American craftsmanship. Free trade opponents believe that the "Made in the U.S.A." label is more important than less expensive imports but this argument misses the substantial gains of increased trade, including increased exports, higher paying jobs, and an improved standard of living. America's domestic market is already accessible to foreign products. Only through strong, negotiated trade agreements can the United States reduce foreign barriers to its own goods. Laborers, Wall Street traders, farmers, and professionals all stand to gain from liberalized trade yet this point remains widely unknown and unacknowledged by the American public. If Fast Track supporters expect victory, they cannot allow free trade opponents to control the debate as in 1997.

Arguments in favor of Fast Track and the New Economy did not appeal to many undecided members of Congress and the public. Protectionist members, who would have been an unruly minority ten years ago, have rapidly become mainstream. These members used their constitutional power and prerogative to "check" the administration's trade policy goals. Since the disastrous Smoot-Hawley Tariff Act of 1930, the legislative and executive branches have struggled to maintain a workable balance on trade matters but over the past 30 years Congress has continuously enhanced both its oversight and its prescriptive role in trade negotiations. This trend toward substantial congressional involvement in trade matters provided the mechanism for Fast Track's failure.

In the past, trade matters were "just one part of a largely bipartisan foreign policy that rested on support from American political elites. This strategy is no longer effective." 62 Before the collapse of the Soviet Union in 1991, U.S. political and military power offered nations assurance against Soviet aggression and members of Congress acknowledged the need for U.S. involvement abroad. With the threat of communism virtually eliminated and the resulting decrease in military spending, economic leverage has become increasingly important as a tool in influencing foreign nations. Many influential legislators no longer believe that economic interdependence benefits the 
United States and serves international stability, so any move toward economic globalization will be met with fierce resistance. 63

Today, domestic concerns and political constituencies greatly influ ence congressional direction, motives, and rhetoric. The effect of labor interests on Democratic members cannot be underestimated. Labor unions, which assist Democratic members with fundraising and campaigning, cleserted the party following the vote to support NAFTA in 1993, and 40 years of Democtatic hegemony in the House of Representatives came to an end. In 1997, organized labor's increased power proved vital in dissuading the vast majority of Democrats from supporting Fast Track for a Democratic president. ${ }^{64}$

Despite advocating the admirable goals of labor rights and environmental quality, many Democrats were forced into opposing Fast Track by the uncloaked threats of big labor. The rivalry between President Clinton's heir apparent, Vice President Gore, and House Democratic Leader Gephardt increased the dimensions of this clispute over Fast Track renewal as Gephardt allied himself closely with labor's demands. To curtail this opposition, the president should have moved quickly to introduce and push Fast Track through Congress while labor savored the result of its efforts in the 1996 election and Clinton's coattails still held some sway with vacillating members. By entering the process too late, the president created a situation where valuable time was lost which opponents used to achieve the necessary level of resistance to Fast Track.

For Fast Track to succeed, business leaders, the president, and other supporters of free trade must better educate the public about the benefits of decreased trade barriers including our strong economy, the role of expanded trade in building that strength, and the advantageous position of this country to make use of the enormous opportunities presented by a growing global economy. Whereas organized labor is able to easily exploit jobs lost to foreign trading partners, business has not adequately argued that increased exports lead to more and better jobs in the U.S. for Americans. Presidential leadership in this area must be heightened, for despite the fact that "Clinton has presided over remarkable prosperity and economic growth, with international trade playing a major role... he failed to link the two in the public mind." $" 65$

The lesson from the debate over Fast Track in 1997 is clear: without public support, future trade accords will be subjected to opposition from free trade adversaries. The president must work closely with the congressional leadership, free trade advocates, and business leaders to effectively make the connection between international trade, job growth, and the New Economy. State and community leaders, foundation heads, academics, and others must engage in this national effort to show the American people that traditional protectionisn is bankrupt and that agreements which lower bar-

\section{Protectionist}

members, who

would have been

an unruly

minority ten

years ago, have

rapidly become

mainstream. 


\section{Traditional}

\section{protectionism is}

bankrupt and

agreements

which lower

barriers to trade

will benefit the

country and its

financial well-

being through

better jobs, less

expensive goods,

\section{and an improved}

riers to trade will benefit the country and its financial well-being through better jobs, less expensive goods, and an improved economy. Otherwise, future attempts to secure passage of trade agreements will be met with equally fierce and successful opposition, leading to an "era of diminished expectations" where the New Economy is concerned. 66

\section{Notes}

† I would like to acknowledge the alssistance of all who contributed to this article. In particular, I would like to thank Rachel Stein and Peter Troedsson for their late nights, good humor and strength. Finally, I would like to express my deep admiration for Dr. Kathy Newcomer, whose support during my time in the program has been invaluable.

1 The New Economy describes the shift from a manufacturing economy to an information based, high technology, service industry economy in which decreased trade barriers, international competition, and access to foreign markets are integral to U.S. tracle policy.

2 New Democrats are socially moderate, fiscally responsible, pro-growth Democrats who are working to find mainstream, bipartisan solutions to the nation's problems. New Democrars work on many issues dealing with the New Economy, international trade and education.

3 The "precise constitutional division of labor in international tracle matters between the President and Congress has been ambiguous because trade, by its nature, appears to overlap the jurisdiction of the two branches." See Harold Koh, "History of FastTrack Approval Mechanism," In Guide to the U.S.-Canada Free-Trade Agreement, Judith H. Bello and Alan F. Holmer, eds. Englewood Cliffs, NJ: Prentice Hall Law and Business, $1992, \$ 1.01$.
4 The president, as the nation's chief executive, exercises implied power over foreign relations through the Constitution's grant of explicit authority to be commander in chief, appoint ambassadors, and make treaties with the advice and consent of twothirds of the Senate. (U.S. Constitution, Art. II, 92.) In U.S. v. Curtiss-Wright Export Corp., the Supreme Court held that the President was the "sole possessor of external sovereignty... (and into) the field of negotiation the Senate cannot intrucle; and Congress itself is powerless to invalde it." (U.S. v. CurtissWright Export Corp., 299 U.S. 304, 317, 319 [1936]).

5 Congress, according to Article I of the U.S. Constitution, has the power to "regulate Commerce with foreign nations" and to "lay and collect Taxes, Duties, Imposts and Excises,"

${ }^{6}$ Johnny Killian and George Costello, "Analysis and Interpretation of the Constitution of the United States of America," Congressional Research Service Report, 1992, 496.

7 In the Smoot-Hawley Tariff Act of 1930 , Congress single-handedly established the highest tariff levels in U.S. history, leading to the view that "near-total congressional control of international trade is synonymous with destructive substantive policies of trade protectionism." Within four years of that clecision, Congress reversed itself and provided the president broad authority to develop and negotiate U.S. trade policy in the Reciprocal Trade Agreements Act of 1934. Koh, in Bello and Holmer, eds. $\$ 1.01$ [a].

${ }^{8}$ PL. 93-618.

9 Harold H. Koh, "The Fast Track and United States Trade Policy," Brooklyn Journal of International Law 18, (1992): 143.

10 Alan Wolf, "The U.S. Manclate for Tracle Negotiations," Virginia Joumal of International Law 16, (Spring 1976): 516.

11 Koh, in Bello and Holmer, eds. $\$ 101[\mathrm{dl}$.

12 See Sections 102 and 151 of PL. 93-618. 
13 A legislative veto is any clevice in a law that subjects aclministrative action to Congressional oversight or control. For example, a legislative veto in a law authorizing the budget for an actministrative agency may dictate that the agency may not take certain steps without informing Congress and even then these agency alctions can be overturned by vote of a congressional committee or one or both houses of Congress.

14 The two-house disapproval procedure was applicable to decisions on import relief actions when they cliffered from the recommendations of the U.S. International Trade Commission. The one-house disapproval procedure was applicable to decisions on countervailing duties, bilateral agreements with Communist countries entered into before enactment of the law, and all annual reviews of most-favorednation (MFN) status. ("Almanac of the 2nd Session of the 93rd Congress," Congressional Quarterly, 1974, 544.)

15 The primary legal issue surrouncling the legislative veto is its relationship to the Constitution, which states in Article I that Congress acts bicamerally and presents bills to the president for signature or veto. In other words, the Constitution gives the president, not Congress, the power to veto. Accordingly, the Court invalidated the legislative veto. See generally Immigration and Naturalization Service v. Cbadba, 462 U.S. 919 (1983).

16 In 1988, the House Rules Committee was adcled to the list of "gatekeeper" committees. See PL. 100-449.

17 PL. 98-573.

18 Harold H. Koh, "The Fast Track and United States Trade Policy," Brooklyn Jonrnal of International Law 18, (1992): 149.

19 Indeed, the president was required to notify and consult with the responsible committees of Congress before beginning negotiations, throughout the negotiating process, and as the implementing language was being drafted to ensure the final legislation could be managed under the expedited Fast Track procedure.
${ }^{20}$ In order to deflect opposition, Representative Dan Rostenkowski (D-IL) and Senator Lloyd Bentsen (D-TX), chairs of the two key gatekeeper Committees, urged Presiclent Bush to provide an action plan outlining his efforts to include additional protections in these areas as well as proposals to be included in the implementing legislation to assist workers dislocated ats a result of NAFTA. The president agreed and due to this cooperative executivecongressional action, the Resolutions of Disapproval failed in both bodies. See Harold H. Kol, "The Fast Track and United States "Trade Policy," Brooklyn Journal of International Law 18, (1992): 153-5.

21 Interestingly, just as Republican President Bush battled a Congress controlled by Democrats for the authority to continue negotiations in 1991, President Clinton, a Democrat, encountered equally antagonistic opposition from his own party when he completed NAFTA and sent the measure to Congress under Fast Track rules in November of 1993.

22 See generally "Deals for NAFTA Votes: Trick, No Treat." Public Citizen, October 1997.

\section{PL. 103-182.}

${ }^{24}$ Recognizing that domestic labor and environmental organizations are among Democratic members' staunchest allies, U.S. Trade Representative Charlene Barshefsky, the president's chief negotiator on trate matters, emphasized the Administration's efforts to shore up support in these areas. In the conclusion of her testimony on Fast Track to the House Ways and Means Committee, Ambassador Barshefsky stated that "the challenge is how to maximize progress in three areas which are of major importance to us; expancled market access, advancing worker rights and core labor standards, and promoting environmental protection and sustainable development." (House Committee on Ways and Means, Hearing on Fast Track, 105th Cong., 1st sess., 1997. Testimony of U.S. Trade Representative Charlene Barshefsky, 18 March 1997, 14.)

25 Congressional Record, 105th Cong., 1st sess., 4 November 1997, $\$ 11632$. 
26 Ronald D. Elving, "Gephardt: Fast Track to Spotlight," Congressional Quarterly, 15 November 1997, 2868.

27 Editorial, "Fast Track for President," Contra Costa Times, 02 September 1997, A11.

28 Conversation with labor lobbyist, April 1997.

29 Pl. 100-449, Section 1101.

30 These standards include the right to organize and bargain collectively, the right to strike, the prohibition of forced labor and employment discrimination, protections for migrant workers and children, and standards on wages, overtime and occupational hazards. See generally Mary Jane Bolle, "NAFTA Labor Side Agreement: Lessons for the Worker Rights and Fast-Track Debate," Congressional Research Service Report, 17 October 1997, 4.

31 In testimony before the Senate Finance Committee, environmentalists listed specific negotiating objectives which should be included in Fast Track, including measures to "(i) safeguard legitimate U.S. and international environmental, health, and safety laws and regulations; (ii) ensure that investment and trade agreements require international businesses to comply with high environmental standards no matter where they operate; (iii) ensure that our trading partners adopt and enforce strong environmental protections consistent with their sovereign rights to establish appropriate domestic policies; and (iv) ensure that dispute resolution mechanisms are accessible to the public and utilize environmental expertise." (Senate Committee on Finance, Hearing on Fast Track, 105th Cong., 1st sess., 1997. Testimony of National Wildife Federation President Mark Van Putten, 3 June $1997,4-5$.
32 For example, for the first time, institutions exist to tackle cross-border pollution and to investigate enforcement of national environmental protection laws. The Administration maintained that its record demonstrates that it has negotiated agreements related to labor and the environment at every opportunity. See Office of the President of the United States, "Study on the Operation and Effects of the North Americaln Free Trade Agreement," July 1997, 111.

33 America Leads On Trade, State-by-state information. Available at: http://www.fasttrack.org; INTERNET.

34 I.M. Destler, "Getting Back on Track," The New Democrat, January/February 1998, 17.

35 Editorial, "What Fast Track Means," The Washington Post, 22 May 1991, A-20.

36 Mary Jane Bolle, "NAFTA Labor Sicle Agreement: Lessons for the Worker Rights and Fast-Track Debate," Congressional Research Service Report, 17 October 1997, 2.

37 Secretary of State Madeleine K. Albright, "Letter to members of Congress," 4

November 1997.

38 David LaGesse, "Trading Blame," The Dallas Morning Neus, 11 November 1997, A1.

39 Ray Moseley, "Mrs. Clinton Chides Business Leaders at Forum," Chicago Tribune, 3 February 1998, A-4.

40 Tom Baxter, "Trade Bill Snafu Puts Clinton on Fast Track to Lame Duck," The Atlanta Joumal, 13 November 1997, A-21.

41 For example, the Fast Track bill established negotiating objectives and priorities, required extensive consultation with Congress, and outlined time limits and restrictions on debate. It also continued the tradition of an up-or-down vote, without amenclments, on implementing legislation. 
42 The president sought to accomplish these goals by working through the World Trade Organization (WTQ) and the International Labor Organization (ILO). See George Holliclay, "Fust-Track Authority: The Debate Over Reauthorization," Congressional Research Service Report, 10 October 1997.

43 In the Senate, Chairman Roth (R-DE) passed $\mathrm{S}, 1269$ out of the Finance Committee by voice vote on October 1, 1997. See S.Rpt. 105-102, U.S. Congress, Senate Committee on Finance. The Reciprocal Trade Agreements Act of 1997, S. 1261. 105th Cong., 1st sess., 1997.

44 For an in-clepth analysis of the differences between the House and Senate versions, see Jeanne Grimmett, "Fast-Track Trade Negotiating Proposals: A Comparison of H.R. 2621 and S. 1269," Congressional Research Service Report, 22 October 1997.

45 H.Rpt, 105-341.

46 Dissenting Views of Congressman Rangel, H.Rpt. 105-341: 44.

47 James Ridgeway, "Odd Capitol Couplings," The Village Voice, 25 November 1997, 35.

48 Thomas B. Edsall and John E, Yang, "Clinton Loss Illuminates Struggle Within Party," The Wasbington Post, 11 November 1997, A-1.

${ }^{49}$ Rory O'Connor, David Hessand, and Maria Recio, "Trade Bill Vote Put Off for Two Days," San Jose Mercury News, 8 November 1997, A-1.

${ }^{50}$ Anclrew Taylor, "Clinton Loses First Opportunity After All-Out Fast Track Pusli," Congressional Quarterly, 08 November 1997, 2754 .

51 Alexis Simendinger, "A Slow Trip on Fast-Track," National Journal, 27 September 1997, 1896-7.

${ }^{52}$ Interestingly, the Free Trade Act of 1974 included the Jackson-Vanik Amendment which requires the yearly extension of Most Favored Nation status to any communist country which prohibits free emigration of its citizens.
53 Alexis Simendinger, "A Slow Trip on Fast-Track," National Journal, 27 September 1997, 1896.

54 For example, the executive has the ability, according to Article II, Section 3, of the Constitution, to "recommend to [the] Consideration [of Congress] such Measures he shall judge necessary and expedient." Furthermore, the president has the authority to explain the necessity of the proposial and why it should be supported. Finally, he can provide favors to members of Congress by supporting their local projects and raising funds for re-election campaigns.

55 John F. Harris, "Presiclent Takes Blame for Fast Track Delay," The Wasbington Post, 11 November 1997, A-1.

56 Lester Seligman and Cary Covingron, "Presidential Leadership with Congress: Change, Coalitions, and Crisis," in Rivals for Power, James A. Thurber, ed. (Washington, D.C.: CQ Press), 1996.

57 David Hess and Maria Recio, "Trade Bill Backers Scramble," San Ramon Valley Times, 10 November 1997, A-1.

58 See Louis Fisher, The Politics of Shared Power, (Washington, D.C.: CQ Press, 1993), $38-50$.

59 David LaGesse, "Trading Blame," The Dallas Monning News, 11 November 1997. A1.

${ }^{60}$ John F. Harris, "President Takes Blame for Fast Track Delay," The Wasbington Post, 11 November 1997, A-1.

61 President William Jefferson Clinton, "Statement of President Clinton," The White House, 10 November 1997. Available at www, whitehouse,gov/library; INTERNET.

62 David Dreier, "It's Time to Take Free Trade to the American People," Roll Call, 9 March 1998, A-14.

63 In the 105th Congress, only 190 members of the House and 60 members of the Senate were in office before the Cold War encled. 
64 Despite his pro-labor record, labor groups impeded President Clinton's attempt to revive Fast Track by curtailing support from his own party.

65 I.M. Destler, "Getting Back on Track," The Neu' Democrat, January/February 1998, 17.

66 John Maggs, "US Must Be Content with Mere Scraps at World Trade Table," Journal of Commerce Staff, 30 January 1998, A-1.

\section{BIBLIOGRAPHY}

Albright, Secretary of State Madeleine K. "Letter to Members of Congress," 4 November 1997.

"Almanac of the 2nd Session of the 93rd Congress." Congressional Quarterly, 1974,544 .

America Leads on Trade. "State-by-State Analysis of Trade Impacts." Available from www.fasttrack.org; INTERNET.

Baxter, Tom. "Trade Bill Snafu Puts Clinton on Fast Track to Lame Duck." The Atlanta Journal, 13 November 1997, A21.

Bolle, Mary Jane. "NAFTA Labor Side Agreement: Lessons for the Worker Rights and Fast-Track Debate." Congressional Researcb Service Report, 17 October 1997, 2, 4.

Clinton, President William Jefferson, "Statement by the President." The White House, 10 November 1997. Available from www.whitehouse gov/library; INTERNET:

Congressional Record. 105th Cong., 1st sess., 1997. Vol. 143, pt. 152, $\$ 11632$.

Destler, I.M. "Getting Back on Track." The New Democrat, January/February 1998 , 17.

Dreier, David. "It's Time to Take Free Trade to the American People." Roll Call, 9 March 1998, A-14.

Editorial, "Fast Track for the President." Contra Costa Times, 2 Septenaber 1997. A-11.
Editorial, "What Fast Track Means," The Wasbington Post, 22 May 1991, A-20.

Edsall, Thomas B. and John E. Yang. "Clinton Loss Illuminates Struggle Within Party." The Wasbington Post, 11 November 1997, A-1.

Elving, Ronald D. "Gephardt: Fast Track to Spotlight." Congressional Quarterly, 15 November 1997, 2868.

Fisher, Louis. The Politics of Shared Power. Washington, DC: CQ Press, 1993.

Grimmett, Jeanne. "Fast-Track Trade Negotiating Proposals: A Comparison of H.R. 2621 and S. 1269." Congressional Research Service Report, 22 October 1997.

Harris, John F, "President Takes Blame for Fast Track Delay," The Wasbington Post, 11, November 1997, A-1.

Hess, David and Maria Recio. "Trade Bill Backers Scramble." San Ramon Valley, Times, 10 November 1997, A-1.

Holliday, George. "Fast-Track Authority: The Debate Over Reauthorization." Congressional Researcb Service Repont, 10 October 1997.

House Committee on Ways and Means, Hearing on Fast Track, 105th Cong., 1st sess., 1997. Testimony of U.S. Trade Representative Charlene Barshefsky, 18 March 1997, 14.

Immigration and Naturalization Service $v$. Chadba. 462 U.S. 919 (1983).

Killian, Johnny and George Costello. "Analysis and Interpretation of the Constitution of the United States of America." Congressional Research Service Report, 1992, 496.

Koh, Harold H. "The Fast Track and United States Trade Policy," Brooklyn Journal of International Law 18, (1992): 149-155.

Koh, Harold H. "History of Fast-Track Approval Mechanism." In Guide to the U.S.-Canada Free-Trade Agreement,

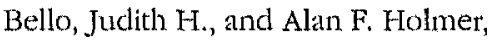
eds. Englewood Cliffs, NJ: Prentice Hall Law \& Business, 1992, 1-17. 
LaGesse, David. "Trading Blame." The Dallas Morning News, 11 November 1997, A-1.

Maggs, John. "US Must Be Content with Mere Scraps at Workl Tracle Table." Joumal of Commerce Staff, 30 January 1998, 1-A.

Moseley, Ray. "Mrs. Clinton Chides Business Leaders at Forum." Chicago Tribune, 3 February 1998, A-4.

Office of the President of the United States. Siudy on the Operation and Effects of the North American Free Trade Agreement, July 1997, 111.

O'Connor, Rory, David Hessand, and Maria Recio. "Trade Bill Vote Put Off for Two Days." San Jose Mercury Neus, 8 November 1997, A-1.

Public Citizen. "Deals for NAFTA Votes: Trick, No Treat," October 1997.

Public Law 618, 93rcl Cong, 2nd sess. The Trade Act of 1974.

Public Law 573, 98th Cong, 2nd sess. The Trade and Tariff Act of 1984.

Public Law 449, 100th Cong., 2nd sess. The United States-Canada Free-Trade Implementation Act of 1988.

Public Law 182, 103rd Cong., 1st sess. The Nortb American Free Trade Agreement Implementation Act of 1993.

Ridgeway, James. "Odd Capitol Couplings." The Village Voice, 25 November 1997 , 35.

Seligman, Lester and Cary Covington. "Presidential Leadership with Congress: Change, Coalitions, and Crisis," in Rivals for Power, James A. Thurber, ed, Washington, DC: CQ Press, 1996.

Senate Committee on Finance, Hearing on Fast Track, 105tl Cong., 1st sess., 1997. Testimony of National Wildlife Federation President Mark Van Putten, 3 June 1997, 4, 5.

Simendinger, Alexis, "A Slow Trip on FastTrack." National Journal, 27 September 1997, 1897-97.

Taylor, Andrew. "Clinton Loses First Opportunity After All-Out Fast Track Push." Congressional Quarterly, 8 November 1997, 2754.
U.S. Congress. House Committee on Ways and Means. The Reciprocal Trade Agreement Authorities Act of 1997, H.R. 2621. 105th Cong., 1st sess., 1997. H.Rpt. 105-341.

U.S. Congress, Senate Committee on Finance. The Reciprocal Trade Agreements Act of 1997, S. 1261. 105th Cong., 1st sess., 1997. S.Rpt. 105-102.

U.S. v. Curtiss-Wright Export Corp., 299 U.S. 304, (1936).

Wolf, Alan. "The U.S. Mandate for Trade Negotfations." Virginia Joumal of International Law 16, (Spring 1976): 516. 
